\title{
PENGARUH HUKUM ADAT ATAU AWIG-AWIG TERHADAP PENGELOLAAN DANA DESA DI DESA BANJAR KECAMATAN BANJAR KABUPATEN BULELENG PROVINSI BALI
}

\author{
Kadek Ayu Monica Pastika Putri, Ni Wayan Fenni Puspitasari, Ni Ketut Krisna \\ Dewi, Ni Wayan Ekarini, Ida Ayu Putu Priska Dewi, Dewa Putu Kodi Mertadana \\ Jurusan Akuntansi, Universitas Pendidikan Ganesha, Singaraja, Buleleng, Bali
}

\begin{abstract}
Abstrak
Penelitian ini bertujuan untuk mengetahui pengertian awig-awig desa dan Desa Adat, bagaimana Dasar Hukum dari penyelengaraan Desa Adat di Bali dan Dasar Hukum Pengelolaan Dana desa, serta apakah Hukum Adat dan Awig-awig berpengaruh pada Pengelolaan Dana Desa di Bali. Penelitian yang dilakukan mengambil sampel di Desa Banjar Kabupaten Buleleng Provinsi Bali melalui metode wawancara dan dokumentasi. Hasil penelitian menunjukkan bahwa pengelolaan dana desa ada dipengaruhi oleh awig-awig desa adat dalam penentuan pengambilan keputusan karena dana desa diserahkan dan pemerintah desa secara langsung diberikan wewenang untuk mengurus dana yang telah diberikan. Dalam sisitem desa adat pengelolan dana desa adat melibatkan masyarakat desa dalam pengelolaannya dan dari sebagian desa adat dibali pengelolaan dan desanya dipengruhi oleh kebijakan desa adat itu sendiri dan hukum desa adatnya.
\end{abstract}

Kata kunci: awig-awig; dana desa; desa Banjar

\section{Abstract}

This study aims to determine the understanding of awig-awig villages and Adat Villages, how the Legal Basis of organizing Adat Villages in Bali and the Legal Basis for Village Fund Management, and whether Adat and Awig-awig Laws affect the Management of Village Funds in Bali. The study was conducted to take a sample in Banjar Village, Buleleng Regency, Bali Province through interview and documentation methods. The results showed that the management of village funds was influenced by customary village awig-awig in determining decision making because village funds were handed over and the village government was directly given authority to manage the funds that had been given. In the traditional village system the management of the customary village funds involves the village community in its management and from some of the traditional villages the management and the village are influenced by the customary village policy itself and the customary village law.

Keywords: awig-awig; village fund; Banjar village

\section{Pendahuluan}

Dana desa merupakan dana yang bersumber dari anggaran pendapatan dan belanja Negara yang diperuntukan bagi desa dan adat yang ditransfer melalui anggaran pendapatan dan belanja kabupaten/kota dan digunakan untuk pembiayaan penyelenggaraan pemerintahan, pembangunan, serta pemberdayaan masyarakat. Berdasarkan Peraturan Pemerintah No. 60 Tahun 2014 tentang pengelolaan dana desa yang bersumber dari APBN, dengan luasnya lingkup kewenangan desa dan dalam rangka mengoptimalkan penggunaan Dana Desa yang diperioritaskan untuk membiayai pembangunan dan pemberdayaan masyarakat Desa, penetapan perioritas pembangunan dana tersebut tetap sejalan dengan kewenangan yang menjadi tanggung jawab Desa. Dalam setiap desa yang ada di Indonesia pastinya mempunyai cara pengelolaan Dana Desanya tersendiri, begitupula yang ada dibali pengelolaan Dana Desa di Bali selalu berlandaskan akan Hukum Adat di masing - masing desa. Hukum Adat di Bali telah ada sejak dulu yang merupakan warisan dari leluhur. Masyarakat Bali, khususnya etnis Bali yang beragama Hindu, terkenal dengan kehidupan adat dan budayanya. Sebagai warga Negara Indonesia, masyarakat Bali tentunya tunduk kepada Hukun Negara yaitu Perundang-Undangan Republic Indonesia. Hukum adat bali bagi masyarakat bali merupakan suatu petunjuk jalan, dan batasan dalam melakukan suatu 
perbuatan dalam ranah hukum adat. Hingga begitu kentalnya hukum adat bali ini tidak dapat dipisahkan dari ajaran agama, sehingga sulit bagi kita untuk membedakan antara hukum adat, dan mana agama, karena dalam hukum adat bali antara adat dan agama ini seolah menyatu, saling keterkaitan. Begitupula dengan pengelolaan Dana Desa yang telah diatur oleh Pemerintah Desa walapun ada system pemerintah tetapi hukum adat di Bali pasti selalu digunakan dalam kegiatan apapun. Sebagai dasar dari pengikat dan pengatur semua aspek yang terjadi di Desa adat.

Dari permasalahan di atas, dapat dirumuskan beberapa rumusan masalah yaitu apa itu awig-awig desa dan Desa Adat, bagaimana Dasar Hukum dari penyelengaraan Desa Adat di Bali dan Dasar Hukum Pengelolaan Dana desa, serta apakah Hukum Adat dan Awig-awig berpengaruh pada Pengelolaan Dana Desa di Bali.

\section{Hasil dan Pembahasan}

\subsection{Pengertian awig-awig desa dan Desa Adat}

Sama halnya didalam sebuah Negara yang memiliki undang - undang atau hukum dasar yang mengatur kehidupan warganya dan sebuah organisasi yang memiliki anggaran dasar rumah tangga yang digunakan sebagai pedoman dalam menjalankan organisasinya. Begitu juga dengan desa pakraman yang merupakan sebuah lembaga adat juga mempunyai hal serupa. Desa pakraman di Bali memiliki sebuah aturan adat yang digunakan sebagai aturan khusus untuk mengatur kehidupan masyarakat adat dalam wilayah kehidupan desa pakraman diluar kehidupan desa dinas yang berpedoman pada hukum nasional/Negara. Awig -awig brasal dari kata "wig" yang artinya rusak sedangkan "awig" artinya tidak rusak atau baik. Jadi awig - awig dimaknai sebagai sesuatu yang menjadi baik. Secara harfiah awig - awig memiliki arti suatu ketentuan yang mengatur tata karma pergaulan hidup dalam masyarakat untuk mewujudkan tata kehidupan yang ajeg di masyarakat. Sedangkan dalam Perda Nomor 3 Tahun 2001 Tentang Desa Pakraman dan Lembaga Adat, menyatakan. Awig - awig adalah aturan yang dibuat oleh karma desa pakraman masing - masing. Dalam Peraturan Daerah Provinsi Bali Nomor 3 Tahun 2003 disebutkan bahwa Hukum Adat (awig awig dan pararem) adalah hukum adat Bali yang hidup dalam masyarakat Bali yang bersumber dari Catur Dresta serta dijiwai oleh Agama Hindu Bali. Catur Dresta yakni, Sastra Dresta yakni ajaran - ajaran agama, Kuna Dresta yakni nilai - nilai budaya, Loka Dresta yakni pandangan hidup dan Desa Dresta yakni adat istiadat setempat.

Karakteristik yang dapat ditemui dalam awig - awig, diantaranya adalah :

1) Bersifat sosial religius, yang tampak pada berbagai tembang - tembang, sesonggan, dan pepatah - petitih. Untuk membuat sebuah awig - awig harus menetukan hari baik, waktu, tempat dan orang suci yang akan membuatnya, hal ini dimaksudkan agar awig - awig itu memiliki charisma dan jiwa/taksu. Awig - awig yang ada di desa pakraman tidak saja mengatur maslah bhuwana alit (kehidupan social) tapi juga mengatur bhuwana agung (kehidupan alam semesta). Hal inilah yang mendorong Masyarakat Bali sangat percaya dan yakin bahwa awig - awig ataupun tidak saja menimbulkan sanksi sekala (lahir) juga saksi niskala (batin).

2) Bersifat konkret dan jelas artinya disini hukum adat mengandung prinsip yang serba konkret, nyata, jelas, dan bersifat luwes. Kaedah - kaedah hukum adat dibangun berdasaekana asas - asas pokok saja, sedangkan pengaturan yang bersifat detail diserahkan pada pengolahan asas - asas pokok itu dengan memperhatikan situasi dan kondisi masyarakat. Jadi ari sini akan muncul peraturan adat lain seperti pararem sebagai aturan tambahan yang berisi petunjuk pelaksana, aturan tambahan, dan juga bisa saja sanksi tambahan yang belum ada, sudah tidak efektif atau belum jelas pengaturannya dalam awig - awig.

3) Bersifat dinamis, hukum adat tumbuh dan berkembang dalam masyarakat. Ketika masyarakat berubah karena perkembangan zaman, hukum adat ikut berkembang agar mampu mengayomi warga masyarakat dalam melakukan hubungan hukum dengan sesamanya.

4) Bersifat kebersamaan atau komunal. Dalam Hukum Adat Bali tidak mengenal yang namanya Hakin Menang Kalah, namun yang ada adalah Hakim Perdamaian. Karena 
Hukum Adat Bali lebih mementingkan rasa persaudaraan dan kekeluargaan. Setiap individu mempunyai arti penting di dalam kehidupan bermasyarakat, yang diterima sebagai warga dalam lingkungan sosialnya. Dengan demikian, hukum adat menjaga keseimbangan kepentingan bersama dengan kepentingan pribadi. Dalam awig - awig desa pakraman menjaga keseimbangan tiga aspek kehidupan manusia merupakan hal terpenting serta inilah yang membedakan awig - awig dengan hukum adat lainnya. Kita ketahui bersama masyarakat Bali dikenal sebagai masyarakat yang memiliki sifat komunal dan kekeluargaan dalam kehidupan kesehariannya, artinya manusia menutur hukum adat setiap individu mempunyai arti penting di dalam kehidupan bermasyarakat mempunyai ikatan yang erat, rasa kebersamaan ini meliputi seluruh lapisan hukum adat.

5) Karakteristik lainnya dari awig - awig yakni tidak seperti hukum nasional atau hukum barat yang jarang mengakomodir dimensi sosialisasi, hukum adat sebaliknya lebih mengkomodir simensi sosiologis. Dengan demikian, alam pembangunan hukum nasional, hukum adat menjadi bahan - bahan dalam pembentukan peraturan perundang undangan, sedangkan lembaga - lembaga hukum adat seperti lembaga keamanan tradisional yang disesuaikan dengan perkembangan zaman dapat digunkan dalam penegakan hukum.

Awig - awig yang hidup dalam masyarakat tidak hanya membedakan hak dan kewajiban melainkan juga memberikan sanksi - sanksi adat baik berupa sanksi denda, sanksi fisik, maupun sanksi psikologi dan yang bersifat spiritual, sehingga cukup dirasakan sebagai derita oleh pelanggaranya. Sanksi adat adalah berupa reaksi dari desa pakraman untuk mengembalikan keseimbangan magis yang terganggu. Jenis - jenis sanksi adat yang diatur dalam awig - awig maupun pararem antara lain :

a. Mengaksam (minta maaf)

b. Dedosaan (denda uang)

c. Kerampang (disita harta bendanya)

d. Kasepekan (tidak diajak bicara) dalam waktu tertentu

e. Kaselong (diusir dari desanya)

f. Upacara Prayascita (upacara bersih desa) (Sirtha, 2008:32)

\section{Desa Adat}

Desa adat di Bali dimulai masuknya kekuasaan pemerintah Hindia Belanda ke Bali Selatan (1906-1908) menggantikan posisi kerajaan atas desa-desa di Bali. Dalam penyelenggaraan pemerintahan di Bali, pemerintahan kolonial Belanda menerapkan dua sistem pemerintahan; sistem pemerintahan langsung di bawah Belanda dan sistem pemerintahan sendiri oleh raja-raja yang disebut dengan daerah swapraja. Dalam penyelengaraan pemerintahan, Pemerintah Belanda memanfaatkan Perbekel sebagai wakilnya untuk mengawasi keadaan di desa. Dengan Perbekel yang diangkat sendiri, Belanda membangun suatu lembaga administrasi di tingkat desa dengan membentuk desa baru bentukan pemerintah kolonial. Dengan desa yang baru diharapkan didalamnya akan terdapat 200 orang penduduk desa yang siap menjalankan tugas-tugas rodi (Desaadat, 2003). Dengan demikian muncul dualisme desa yaitu desa adat dan desa dinas. Urusan agama dan adat dipegang oleh desa adat, sedangkan urusan administrasi pemeintahan dilakukan oleh desa dinas. Fungsi desa dinas adalah dalam lapangan pemerintahan umum, kecuali adat dan agama, sedangkan pengairan/ pertanian dikelola oleh Subak. Dengan demikian desa dinas dapat juga dianggap sebagai desa administrative dalam arti tertentu, karena tugasnya sekedar melaksanakan urusan administrasi pemerintahan. Kerangka paradigmatik pengaturan politik oleh negara kolonial Belanda dilanjutkan oleh UU No. 5 Tahun 1979 yang dapat dilihat dari dua tataran. Pertama, penerusan politik dualisme desa dimana pengaturan politik yang dibangun Negara memungkinkan tetap terjadinya dualisme pengertian desa di Bali yakni desa dinas (Keperbekelan) dan desa adat (Desa Pakraman). Desa dinas dijadikan desa yang menjadi perangkat pemerintahan terendah dan langsung di bawah camat. Sedangkan desa pakraman tetap mendapatkan pengakuan lewat pasal 18 UUD 45. 


\section{Desa adat Pasca UU No. 22 Tahun 1999}

Bergulirnya era otonomi daerah, menimbulkan pergeseran paradigma dalam melihat desa adat. Pergeseran itu terlihat dari beberapa kasus :

1) Dikeluarkannya Perda tentang Desa Pekraman tahun 2001 yang terkesan lebih aspiratif, memperkuat dan menghargai eksistensi desa adat di Bali, sebagai pengganti Perda No. 6/1986 yang sebelumnya mengatur tentang Desa adat;

2) Adanya sejumlah konsensi ekonomi yang diberikan pemerintah Propinsi dan Kabupaten kepada desa adat, seperti Pemerintah Propinsi Bali memberikan sepeda motor pada Bendesa Adat, dan Pemerintah Kabupaten Tabanan mengikutsertakan Desa Adat Beraban dalam mengelola obyek wisata Tanah Lot, dan memberi $35 \%$ keuntungan pada Desa Adat Beraban;

3) Desa adat diikutsertakan dalam proses pengambilan kebijakan dan penyelenggaraan pemerintahan sehari-hari di tingkat desa, misalnya ijin investasi harus mendapatkan persetujuan desa adat, dan setiap pendatang harus mendapatkan rekomendasi dari desa dinas dan desa adat.

Namun demikian, ada beberapa masalah mendasar yang dihadapi oleh desa adat di Bali, seperti masalah otonomi desa adat dan demokratisasi adat. Berkaitan dengan otonomi desa adat, permasalahan yang dihadapi adalah : (1) Dualisme pemerintah desa, (2) Belum jelasnya tata hubungan Kabupaten-Desa Adat, (3) Dualisme hukum dengan adanya pengakuan desa adat sebagai entitas hukum, (4) Munculnya konflik antar desa menyangkut batas wilayah dan soal tanah-tanah adat, dimana intervensi pemerintah yang tidak tepat menimbulkan eskalasi konflik, (4) Penyeragaman awig-awig hukum dan atau peraturan adat) yang difasilitasi oleh pemerintah dengan format yang baku dan seragam membuat format desa di Bali menjadi homogen, dan (5) Penggunaan pecalang (Satuan petugas keamanan swakarsa adat) untuk kepentingan ekonomi dan politik, seperti menjadi penjual jasa keamanan maupun untuk kepentingan politik (Satgas Partai). Memperhatikan permasalahan yang dihadapi Desa adat seperti diungkapkan di atas, maka beberapa hal yang dapat dilakukan untuk mengatasi permasalahan dan memberdayakan Desa Adat. Penguatan otonomi Desa adat melalui : (a) Rekonseptualisasi hubungan desa adat dan desa dinas, (b) Rekonseptualisasi hubungan desa adat dengan Kabupaten, (c) Pengakuan Hukum dan Pengadilan Adat, (d) Mekanisme penyelesaikan konflik antar desa adat melalui pembentuk lembaga supra desa adat, (e) Politik kebudayaan yang menghargai keunikan setiap desa adat (desa mawa cara) tetapi ada beberapa yang diatur sama untuk menjamin kepastian seperti masalah pendatang, dan (f) Reformulasi dan rekonseptualisasi Pecalang. Pemberdayaan Desa adat melalui : (a) Peningkatan kapasitas kelembagaan desa adat, (b) Demokratisasi desa adat, (c) Semangat pluralisme di desa adat yang tercermin di awig-awig, (d) Penerapan good governance di desa adat, dan (e) Mekanisme penyelesaian konflik yang humanis.

Desa adat di Bali adalah pemerintahan teritorial tradisional yang didalamnya terdapat warga atau krama adat sebagai perwujudan budaya bangsa yang perlu diayomi dan dilestarikan. Dalam pembagian wilayah adat, dijelaskan juga bahwa wilayahnya sudah terbagi - bagi menjadi desa adat yang juga didalamnya terdapat periangan (parahyangan) atau tempat suci seperti Tri Kahyangan sebagaimana dijelaskan dalam sumber kutipan komentar dalam Forum Diskusi Jaringan Hindu Nusantara. Disebutkan pula bahwa desa adat di Bali menurut kutipan dari artikel Parisada Hindu Dharma Indonesia, desa adat selama ini memegang peranan yang sangat penting dalam menata dan membina kehidupan masyarakat desa adat maupun dalam proses pembangunan.

Sebagai organisasi pemerintahan, desa adat merupakan desa otonom asli, mengendalikan roda pemerintahan sendiri di dalam palemahan (wilayah)nya yang tetap hidup dan kedudukannya diakui di dalam Negara Republik Indonesia, Berkenaan

dengan setiap warga desa adat wajib menjunjung kekuasaan yang telah disepakati dalam rangka mewujudkan kehidupan masyarakat yang sejahtera dan tentram seperti yang dicitacitakan, maka bentuk konkrit otonomi Desa adat dapat dilihat pada :

1) Bendesa (Kelihan) Desa adat. sebagai pemimpin tertinggi 
2) Prajuru yang biasanya melayani adat

3) Paruman (Sangkepan) Desa adat, musyawarah yang sangat demokratis

4) Awig-awig Desa adat, aturan-aturan yang dibuat oleh Krama Desa.

Dalam operasionalnya, Desa adat senantiasa mandiri sebagai wujud dari otonomi, karena tidak ada intervensi darimanapun yang dapat dibenarkan dalam rangka mewujudkan kesejahtraan warganya.

Desa adat sebagai masyarakat yang mempunyai tata susunan asli beserta banjarbanjar adat, eksistensinya diakui secara hukum berdasarkan UUD 1945 (pasal 18), dan UU Pemerintahan Desa (UU No.5 Tahun 1979) yang telah dicabut dan digantikan dengan UU No.22 Tahun 1999 begitu pula dengan Permendagri No.3 Tahun 1997 tentang pemberdayaan dan pelestarian dan pengembangan adat-istiadat, kebiasaan-kebiasaan masyarakat dan lembaga adat di daerah.

Pengakuan terhadap desa adat berarti pula pengakuan terhadap lembaga-lembaga adat yang ditetapkan. Keberadaan lembaga-lembaga adat tersebut secara sosiologis masih dipelihara oleh masyarakat desa (krama) adat.

Berdasarkan kenyataan tersebut di atas, eksisitensi desa adat di Bali, Pemerintah Daerah Propinsi Daerah Tingkat I Bali berusaha memelihara keajegan Desa adat Bali dengan menetapkan Peraturan daerah Tingkat I Bali Nomor 06 Tahun 1986 tentang kedudukan, fungsi dan peranan desa adat sebagai kesatuan masyarakat hukum adat dalam Propinsi Daerah Tingkat I Bali, tanggal 25 Juni 1986.

Sebelumnya, Gubernur Kepala Daerah Propinsi Tingkat I Bali mengeluarkan sebuah Keputusan Nomor: 18/Kesra II /C/119/1979, tanggal 21 Maret 1979 tentang Majelis Pembina Lembaga Adat, sebagai sebuah badan yang statusnya semi pemerintah yang mempunyai tugas, fungsi dan wewenang antara lain sebagai badan pertimbangan, saran, usul mengenai permasalahan adat kepada Pemerintah Daerah Tingkat I Bali, dalam rangka pelaksanaan kebijakan Pemerintah Daerah dan dalam penyelesaian konflik adat yang timbul maupun kepada lembaga adat di dalam seluruh aspeknya.

Di samping itu Desa adat berperanan pula dalam pengembangan kawasan wisata, mengawasi penyalah gunaan simbol-simbol keagamaan dan juga berperanan dalam mencegah pendatang liar yang masuk ke Bali, utamanya di wilayah palemahan Desa adat di Bali. Sehingga disebutkan pula bahwa, Perumahan dan Pemulikan Tradisional Bali atau secara tradisional disebut desa adat yang merupakan suatu tempat kehidupan yang utuh dan bulat yang terdiri dari 3 unsur, yaitu: unsur kahyangan tiga (pura desa), unsur krama desa (warga), dan karang desa yang berpola tradisional dengan perangkat lingkungan dengan latar belakang norma-norma dan nilai-nilai tradisional.

Menurut Lontar Widhi Sastra disebutkan pelaksanaan upacara yadnya ngusaba nini dan ngusaba desa sebaiknya dilakukan secara bersamaan yang bertujuan untuk tegaknya hati nurani kembali dalam memelihara kebenaran sehingga terhindar dari prilaku yang penuh dosa sebagai bagian dari upacara yadnya yang dilaksanakan di desa adat. Dewasa ini, penanganan masalah keamanan bagi masyarakat Bali menjadi prioritas utama, karena jumlah penduduknya semakin bertambah, semakin heterogen dan hidupnya semakin kompleks, yang nantinya dapat mengganggu ketenteraman dan ketertiban masyarakat sehingga dengan memperkuat fungsi dan peranan pecalang terhadap pelaksanaan swadharmanya dalam desa adat dapat mewujudkan Bali yang aman, nyaman dan tetap terjaga kesuciannya.

Bali menjadi daya tarik tersendiri kehidupan masyarakat, bagi untuk masyarakat asli Bali maupun masyarakat di luar Bali. Kekayaan adat - istiadat dan tradisi yang senantiasa dijaga oleh penduduknya, menjadikan Bali dipandang sebagai masyarakat adat tradisioanl yang tetap bertahan di tengah arus perkembangan zaman. Desa adat sebagai desa dresta adalah kesatuan masyarakat hukum adat di Provinsi Bali yang mempunyai satu kesatuan tradisi dan tata karma pergaulan hidup masyarakat umat Hindu secara turun temutun dalam ikatan Kayangan Tiga atau Kayangan Desa, yang mempunyai wilayah tertantu serta berhak mengurus rumah tangganya sendiri. Sistem keanggotaan Desa Adat di Bali pada prinsipnya ada dua tipe yaitu Desa Adat yang keanggotaannya berdasarkan atas menempati tanah Desa yang disebut karang ayahan desa, dan Desa Adat yang keanggotaannya tidak 
didasarkan atas menempati karang ayahan desa, melainkan berdasarkan atas kehendak ingin mengorganisasi diri dalam wujud suatu Desa Adat. Oleh karena hal tersebut maka terdapatlah tipe Desa Adat yaitu Desa Adat yang keanggotaannya didalam suatu Desa Adat berdasarkan atas menempati karang ayahan desa yang jumlah anggotannya sama dengan jumlah banyaknya karang ayahan desa. Anggota Desa Adat didasarkan atas seseorang yang telah berkeluarga yang bertempat tinggal di suatu wilayah Desa Adat. Untuk hal ini jumlah anggota Desa Adat atau karma ngarep tidak didasarkan atas status seseorang memikul beban kerjanya atau kewajibannya terhadap Desa Adat. Karena itu sistem keanggotaan Desa Adat seperti ini tidak mengenal istilah karma ngarep atau roban, karena semuanya berstatus karma ngarep. Ketentuan yang dijadikan dasar adalah setiap yang telah berkeluarga yang bertempat tinggal dalam suatu wilayah Desa Adat, wajib menjadi anggota Desa Adat atau karma ngarep, tanpa memperhitungkan status tanah tempat tinggalnya.

Suatu Desa Adat di Bali bukan saja merupakan persekutuan teritorial dan menerapkan persekutuan dalam persamaan kepercayaan terhadap tuhan. Identitas Desa Adat di Bali memiliki tiga unsure yaitu wilayah, warga masyarakat, dan Kahyangan Tiga. Dengan tercakupnya unsur ketuhanan di dalam kehidupan Desa Adat di Bali, maka Desa Adat di Bali mencakup pula pengertian sosio religion. Maka dari itu implikasi antara adat dengan agama Hindu di Bali adalah pekat sekali, sehingga sulit memisahkan secara tegas unsure - unsure adat dengan unsure - unsure agama, karena adat - istiadat di Bali didasarkan oleh agama Hindu dan aktifitas agama Hindu didukung ileh adat - istiadat di masyarakat. Dalam susunan struktur organisasi dari Desa Adat terdapat Banjar. Banjar merupakan kelompok masyarakat yang lebih kecil dari Desa Adat dan menjadi bagian dari Desa Adat serta merupakan persekutuan hidup sosial, baik dalam keadaan senang maupun dalam keadaan susah. Kadang - kadang di daerah pegunungan, suatu desa yang sama dengan suatu Dalam proses interaksi tersebut, sering terjadi benturan kepentingan atau kebutuhan. Kepentingan antara individu yang satu dengan yang lain kadang-kadang bersamaan seperti dalam tugas menjaga keselamatan dari berbagai gangguan. Kelompok masyarakat berkembang dari bentuk yang sederhana sampai dengan yang kompleks. Bersamaan dengan itu, timbullah hukum dalam masyarakat, mulai dari yang sederhana sampai pada saatnya menjadi semakin rumit. Corak kehidupan masyarakat diikuti oleh corak hukum yang berlaku pada masyarakat tersebut. Dalam perkembangannya saling pengaruh mempengaruhi. Setiap kelompok masyarakat selalu ada permasalahan sebagai akibat perbedaan antara yang ideal dan aktual, antara yang standar dan yang praktis. menentukan tingkah laku individu. Penyimpangan nilai yang ideal dalam masyarakat seperti pencurian, pembunuhan, pemerkosaan menimbulkan persoalan dalam masyarakat. Dalam situasi demikian, kelompok berhadapan dengan problema untuk menjamin ketertiban bila kelompok tersebut ingin mempertahankan eksistensinya

Ciri manusia yang membedakannya dari mahluk lain adalah keinginannya untuk selalu berubah. Perubahan tersebut terwujud dalam berbagai bentuk tergantung dari situasi dan kondisi yang mempengaruhinya. Suatu hal yang harus diterima adalah apapun bentuk perubahan yang terjadi, pada dasarnya manusia berkeinginan untuk mendapatkan kehidupan yang lebih baik dari sebelumnya.

Perubahan kehidupan yang dilalui manusia pada dasarnya disebabkan oleh faktor internal dan faktor eksternal. Faktor internal merupakan faktor yang muncul dari dalam diri, sedangkan faktor eksternal muncul dari luar diri manusia itu sendiri. Kedua faktor tersebut secara simultan berpengaruh terhadap perubahan yang terjadi dalam diri manusia. Adanya perubahan-perubahan yang dillui manusia akan muncul problamatika dan kesenjangan sosial dari awig awig dibuat untuk mengikat agar perubahan tersebut tidak semakin mempengaruhi dan menyipang dari sebelumnya.

\subsection{Dasar Hukum dari penyelengaraan Desa Adat di Bali dan Dasar Hukum Pengelolaan Dana Desa}

Desa Adat di Bali pada mulanya bernama Desa Krama, sedangkan anggota masyarakat penduduknya disebut Krama Desa yang sampai sekarang masih hidup dalam masyarakat Hindu di Bali. Adat yang merupakan aturan-aturan atau kebiasaan yang 
dianggap telah patut disepakati bersama sebagai aturan tata tertib dalam kehidupan bermasyarakat yang disertai dengan adanya sanksi yang dilaksanakan oleh Kelian Adat. Pemerintahan Desa Pakraman dilakukan oleh pengurus desa pakraman yang disebut Prajuru Desa Pakraman. Sistem pemerintahan Desa Pakraman dipengaruhi oleh tipe Desa yang bersangkutan. Tipe Desa Pakraman yang ada di Bali dikelompokkan dalam tiga tipe Desa yaitu :

1) Desa Baliaga, yaitu desa tua di Bali yang masih kuat mempertahankan sistem kemasyarakatan asli yang dalam jaman kerajaan dulu tidak dipengaruhi oleh sistem kemasyarakatan Majapahit.

2) Desa Apanaga, yaitu desa-desa yang pada jaman kerajaan dahulu sangat intensif mendapat pengaruh dari sistem kemasyarakatan Majapahit.

3) Desa Anyar, yaitu desa yang timbul karena akibat dari perpindahan penduduk yang didorong oleh keinginan mencari lapangan kehidupan. Sebagai suatu masyarakat hukum adat, Desa adat memiliki tata hukum sendiri yang berdasarkan pada adat-istiadat di desa adat setempat. Tatanan hukum yang berlaku di desa adat lazim disebut sebagai awigawig. Semua desa adat di bali memiliki awig-awig untuk mengatur Desa Adatnya. Awigawig disusun dalam suatu dalam suatu rapat krama desa yang disebut sebagai Paruman Desa. Di masa lalu awig-awig Desa Adat tidak ditulis, setelah para prajuru desa mengenal budaya baca tulis maka awigawig yang diputuskan dalam rapat krama atau paruman desa akhirnya di catat.

Awig-awig mulai dikenal masyarakat Bali sejak tahun 1986 setelah keluarnya Peraturan Daerah Tingkat I Provinsi Bali Nomor 6 Tahun 1986 tentang Kedudukan, Fungsi, dan Peranan Desa Adat sebagai Kesatuan Masyarakat Hukum Adat dalam Provinsi Daerah Tingkat I Bali. Sebelum adanya Perda ini, istilah yang dipakai bermacam-macam, diantaranya pangeling-eling, paswara, geguat, awig, perarem, gama, dresta, cara, tunggul, kerta, palakerta, dan sima. Dalam Bab IV Peraturan Daerah Tingkat I Provinsi Bali Nomor 6 Tahun 1986 tentang Kedudukan, Fungsi, dan Peranan Desa Adat sebagai Kesatuan Masyarakat Hukum Adat dalam Provinsi Daerah Tingkat I Bali disebutkan tentang Awig-awig Desa Adat. Pasal 7:

1. Setiap Desa Adat agar memiliki awig-awig tertulis.

2. Awig-awig Desa Adat tidak boleh bertentangan dengan Pancasila, Undang-Undang Dasar 1945 dan Peraturan Perundang-undangan yang berlaku.

Pasal 8:

1. Awig-awig Desa Adat dibuat dan disahkan oleh krama Desa Adat.

2. Awig-awig Desa Adat dicatatkan di Kantor Bupati/Walikotamadya Kepala Daerah Tingkat II yang bersangkutan.

Pasal 9:

Sanksi yang diatur dalam awig-awig Desa Adat tidak boleh bertentangan dengan Peraturan Perundang-undangan yang berlaku dan rasa keadilan dalam masyarakat.Dalam penjelasan Pasal 8 dijelaskan awig-awig Desa Adat digarap oleh Desa Adat yang bersangkutan sampai dibentuk rancangan. Rancangan awig-awig tersebut disampaikan kepada Bupati/Walikotamadya Kepala Daerah Tingkat II yang bersangkutan untuk mendapat persetujuan. Setelah mendapat persetujuan Bupati/Walikotamadya Kepala Daerah Tingkat II yang bersangkutan barulah awig - awig Desa Adat tersebut disahkan oleh Krama Adat. Peraturan Daerah Tingkat I Provinsi Bali Nomor 6 Tahun 1986 tentang Kedudukan, Fungsi, dan Peranan Desa Adat sebagai Kesatuan Masyarakat Hukum Adat dalam Provinsi Daerah Tingkat I Bali selanjutnya diperbarui menjadi Peraturan Daerah Provinsi Bali Nomor 3 Tahun 2001 tentang Desa Pakraman. Ini juga menandai penggunaan istilah desa pakraman yang telah dipergunakan sejak adanya desa di Bali. Peraturan Daerah ini merupakan "aturan payung" yang menjadi dasar bagi peraturan daerah kabupaten/kota di Bali serta mengukuhkan otonomi pada desa pakraman. Dalam pengukuhan otonomi desa pakraman, dasar desa pakraman adalah Pancasila dan Undang-undang Dasar Negara Republik Indonesia 1945. Dasar ini mengadung karakteristik filosofi yang membentuk nilainilai dasar keadilan, kebenaran, dan kepastian bagi setiap aturan yang ditetapkan dari tindakan yang dilakukan dalam lingkup tugas dan wewenang desa pakraman. Asas desa 
pakraman adalah kebudayaan Bali yang mengandung karakteristik etis hukumiah yang menjadi dasar sumber material aturan yang ditetapkan. Landasan desa pakraman adalah Tri Hita Karana yang mengandung karakteristik konstitutif yang menjadi tolok ukur spiritual etis bagi keseluruhan dasar-dasar yang disucikan dalam perikehidupan desa pakraman. Dalam pasal 1 angka (11) Peraturan Daerah Provinsi Bali Nomor 3 Tahun 2001 tentang Desa Pakraman menyebutkan, awig-awig adalah aturan yang dibuat oleh krama desa pakraman dan atau krama banjar pakraman yang dipakai sebagai pedoman dalam pelaksanaan Tri Hita Karana, sesuai dengan desa mawacara dan dharma agama desa pakraman/banjar pakraman masing-masing. Dalam Bab VII tentang Awig-awig Desa Pakraman mengatur tentang Pasal 11;

1. Setiap desa pakraman menyuratkan awig-awig-nya2.

2. Awig-awig desa pakraman tidak boleh bertentangan dengan agama, Pancasila, Undangundang Dasar 1945, dan hak asasi manusia.

Pasal 12

1. Awig-awig desa pakraman dibuat dan disahkan oleh kraman desa pakraman melalui paruman desa pakraman.

2. Awig-awig desa pakraman dicatatkan di kantor Bupati/Wali Kota masing-masing.

Dalam Pasal 18B ayat (2) UUD NRI 1945 disebutkan "Negara mengakui dan menghormati kesatuan-kesatuan masyarakat hukum adat beserta hak-hak tradisionalnya sepanjang masih hidup dan sesuai dengan perkembangan masyarakat dan prinsip Negara Kesatuan Republik Indonesia yang diatur dalam undang-undang". Apa yang disebutkan sebagai syarat untuk mendapat pengakuan negara tentu harus dipenuhi oleh desa pakraman termasuk awig-awig yang dimiliki. Pengakuan terhadap kesatuan masyarakat hukum adat ini mengandung empat konsekuensi. Pertama, suatu kesatuan masyarakat diakui sebagai suatu kesatuan masyarakat hukum sehingga dapat bertindak sebagai subjek hukum yang berbeda dengan anggota-anggotanya. Kedua, terhadap kesatuan masyarakat hukum adat dapat Dalam hal penemuan hukum, penulisan hukum adat (awig-awig) untuk memudahkan dalam hal menemukan, mengetahui, dan memahami isi ketentuan hukum adat. Dalam bentuknya yang tertulis akan sangat mudah ditemukan oleh kalangan petugas hukum dan generasi yang akan datang. Karena itu, perlu ada keseragaman dan penerbitan dalam bentuk dan sistematikanya. Hal yang tidak terpisahkan dalam penyusunan awig-awig adalah patokan yang digunakan merupakan cerminan dari nilai-nilai Pancasila, antara lain mengatur tentang kewajiban krama dalam kehidupan ber-Ketuhanan Yang Maha Esa; pengakuan martabat yang sama sebagai krama desa; adanya kekompakan dan kesatuan sebagai pengikat; selalu bermusyawarah dalam sangkepan atau paruman; adanya unsur suka-duka dalam kehidupan bermasyarakat serta diikat oleh kehidupan paras-paros. Sebagai hukum yang tumbuh dari bawah, secara sosiologis awig-awig memiliki legitimasi yang kuat dalam masyarakat. Awig-awig diterima dan ditaati di kalangan masyarakat yang berada di wilayah desa pakraman bersangkutan.

Awig-awig jika dilihat dari fungsinya merupakan alat control sosial (hukum sebagai sarana kontrol sosial). Hal ini dilihat dari asumsi awig-awig mampu mengontrol perilaku krama desa dan menciptakan kesesuaian dalam perilaku mereka, baik secara preventif maupun represif.Isi awig-awig di bagian norma harus bersifat moderat dan fleksibel. Hal ini bertujuan mengakomodir kebutuhan perkembangan zaman terutama yang berkaitan dengan kependudukan, kebersihan lingkungan, kesejahteraan, dll. Umumnya awig-awig tertulis hanya memuat pokok-pokok mengenai kehidupan desa pakraman. Aturan pelaksanaan yang lebih rinci dituangkan dalam bentuk keputusan rapat desa yang disebut perarem. Perarem memiliki kekuatan mengikat yang secara substansi bisa dikelompokkan menjadi tiga, perarem penyahcah awig, perarem ngele/lepas, dan perarem penepas wicara. Perarem penyahcah awig artinya aturan pelaksanaan dari awig-awig tertulis yang sudah ada. Perarem ngele berupa keputusan paruman yang merupakan aturan hukum baru yang tidak ada landasannya dalam awig-awig tertulis Hal ini biasanya dipakai untuk mengakomodir kebutuhan hukum baru untuk mengikuti perkembangan masyarakat. Perarem penepas wicara merupakan keputusan paruman mengenai suatu wicara (perkara) yang berupa persoalan hukum seperti sengketa maupun pelanggaran hukum. 


\section{Dasar Hukum Pengelolaan Dana Desa}

Desa sesuai dengan aturan perundang-undangan yang ada memeperoleh hak wewenang dalam mengatur keungnnys sendiri yang terangkum dalam ALokasi Dana Desa (ADD) yang tercantum di dalam Anggaran Pendapatan dan Belanja Daerah (APBD) Kabupaten. Adapun besarnya dana ADD tergantung alokasi dana yang telah ditetapkan untuk masing-masing daerah Kabupaten. Pemberian pengelolaan Keuangan kepada Desa bertujuan agar supaya masing-masing Pemerintah Desa bisa mandiri untuk membangun sendiri desanya sesuai dengan kebutuhan dan Rencana Pembangunan Desa masingmasing. Untuk struktur penyusunan dan pembentukan dasar hukum pengelolaan keuangan desa dimulai dengan terbitnya Undang-Undang Nomor 6 Tahun 2014 tentang Desa yang pengaturannya mulai dari pasal 71 hingga pasal 75. Selanjutnya Peraturan Pemerintah Nomor 43 Tahun 2014 tentang Peraturan Pelaksanaan Undang-Undang Nomor 6 tahun 2014 tentang Desa sebagaimana diubah dengan Peraturan Pemerintah Nomor 47 Tahun 2015 yang pengaturannya mulai dari pasal 90 hingga pasal 106, dan Peraturan Menteri Dalam Negeri Nomor 113 Tahun 2014 tentang Pengelolaan Keuangan Desa.

Di dalam pengaturannya, peraturan perundang - undangan secara berjenjang telah mengatur pengaturan pengelolan keuangan desa dengan Peraturan para daerah (Peraturan Bupati/Wali Kota). Dimulai dengan undang - undang Nomor 6 tahun 2014 tentang Desa sebagaimana diatur dengan pasal 75 ayat (3) "Ketentuan lebih lanjut mengenai keuangan desa diatur dengan Peraturan Pemerintah". Merujuk pasal 75 ayat (3) Undang - undang Nomor 6 Tahun 2014 tentang Desa terbitlah Peraturan Pemerintah Nomor 43 Tahun 2015. Selanjutnya berdasarkan Peraturan Pemerintah Nomor 43 tahun 2014 tentang Peraturan Pelaksanaan Undang - undang Nomor 6 tahun 2014 tentang Desa sebagaimana diubah dengan Peraturan Pemerintah Nomor 47 Tahun 2015, pasal 106 "Ketentuan lebih lanjut mengenai pengelolaan keuangan desa diatur dalam Peraturan Menteri".

Berdasarkan ketentuan pasal 106 Peraturan Pemerintah Nomor 43 Tahun 2014 tentang Peraturan Pelaksanaan Undang - undang Nomor 6 Tahun 2014 tentang Desa sebagaimana diubah dengan Peraturan Pemerintah Nomor 47 Tahun 2015, terbitlah Peraturan Menteri Dalam Negeri Nomor 113 Tahun 2014 tentang Pengelolaan Keuangan Desa.

Dengan terbitnya Peraturan Menteri Dalam Negeri Nomor 113 Tahun 2014 tentang Pengelolaan Keuangan Desa ini, Berdasarkan pasal 43 Peraturan Menteri Dalam Negeri Nomor 113 Tahun 2014 tentang Pengelolaan Keuangan Desa, "Ketentuan lebih lanjut mengenai pengelolaan keuangan desa diatur dalam Peraturan Bupati/Walikota.

Dalam pelaksanaanya pengelolaan dana desa ini diawasi secara langsung oleh BPD (Badan Pengawas Daerah) yang telah diberikan kewenangan dalam mengawasi penggunaan dan Desa agar tidak terjadi kecurangan, tindakan korupsi serta penyelewengan yang dilakukan oleh aparat pemerintah desa. Badan Pengawas Desa ini memiliki dasar hukum dalam menjalankan tugasnya. Dasar hukumnya yaitu : Undang - undang nomor 6 Tahun 2014 tentang Desa Pasal 55 disebutkan Badan Permusyawaratan Desa yang mempunyai fungsi :

1) Membahas dan menyepakati Rancangan Peraturan Desa bersama Kepala Desa

2) Menampung dan menyalurkan aspirasi masyarakat Desa

3) Melakukan pengawasan kinerja Kepala Desa. Peraturan Pemerintah Nomor 43 Tahun 2014 Pasal 48 : Dalam melaksanakan tugas, kewenangan, hak, dan kewajibannya, kepala Desa wajib.

4) Menyampaikan laporan penyelenggaraan Pemerintah Desa pada akhir masa jabatan kepada bupati/walikota

5) Menyampaikan laporan penyelenggaraan Pemerintah Desa setiap akhir tahun anggaran kepada Bupati/Walikota

6) Menyampaikan laporan keterangan penyelenggaraan pemerintah secara tertulis kepada Badan Permusyawaratan Desa setiap akhir tahun anggaran. Peraturan Pemerintah Nomor 43 Tahun 2014 Pasal 51

7) Kepala Desa menyampaiakan laporan keterangan penyelenggaraan Pemerintah Desa sebagaimana dimaksud dalam Pasal 48 huruf c setiap akhir tahun anggaran kepada 
Badan Permusyawaratan Desa secara tertulis paling lambat 3 (tiga) bulan setelah berakhirnya tahun anggaran.

8) Laporan keterangan penyelenggaraan Pemerintah Desa sebagaimana dimaksud pada ayat (1) paling sedikit memuat pelaksanaan peraturan Desa. Laporan keterangan penyelenggaraan Pemerintah Desa sebagaimana dimaksud pada ayat (1) digunakan oleh Badan Permusyawaratan Desa dalam melaksanakan fungsi pengawasan kinerja kepala Desa Maka dari itu, perlu dilakukan beberapa hal agar pemanfaatan dan desa.

Maka dari itu perlu dilakukan beberapa hal agar pemanfaatan dana desa tept sasaran yaitu pembenahan atau mengoptimalkan organisasi pemerintah desa, pemerintah desa yang akuntabel dan transparan, serta pengawasan anggaran. Pertama, kepala desa sebagai top manejemen harus bisa menerapkan fungsi manajemen yaitu perencanaan, pengorganisasian, penggerakan, dan pengawasan untuk mengatur desanya agar lebih maju. Dalam pemilihan kepala desa yang sesuai dan kompeten masyarakat harus mempertimbangkan bibit, bebet, bobot dalam kepala desa tersebut agar sesusai dengan harapan. Dalam mempertimbangkan calon kepala desa pendidikan juga memberikan peranan aktif terhadap perspetif-perspektif yang berkembang di masyarakat serta tidak didasari konstruksi maupun interfensi darimana pun. Setelah kepala desa terpilih, maka kepala desa harus membuat struktur organisasi desa. Pembenahan organisasi pemerintah desa yang dimaksud adalah membuat struktur organisasi desa sesuai kebutuhan agar semua urusan desa dapat diatur dengan baik dan terjadi kesimpangsiuaran seperti penyalahgunaan dana desa serta ketimpangan sosial lainnya. Struktur organisasi di desa harus terdiri dari orang-orang yang memiliki standar kualitas dalam memimpin serta pembentukan badan-badan pengawasan keuangan di pedesaan dan mencari orang yang paham bagaimana cara mengatur desa tersebut. Setelah dibuatkan struktur organisasi desa, maka harus ditetapkan tugas, tanggung jawab dan wewenang dari masing-masing jabatan.

Sebagai calon bagian kepala urusan ekonomi dan pembangun bertugas sebagai penyelenggara urusan perekenomian, dan pembangunan, memiliki tanggung jawab untuk menyelenggarakan pembangunan, dan memiliki wewenang yaitu menjalan serta memberikan inovasi-inovasi pembangunan desa seusai dengan kebutuhan masyarakat sekitar. Dengan diberikannya tugas, tanggung jawab, wewenang serta mencangkup status dan peran yang dimiliki, maka aparatur desa tersebut harus patuh dan menjalankan tugasnya dengan amanah dan memiliki rasa tanggung jawab. Struktur organisasi yang bisa berjalan dengan mengikuti aturan serta terbuka dalam menerima kritiki dan saran akan membuat desanya akan lebih maju dan mendorong masyarakat setempat untuk aktif, sehingga tidak terjadi kekacauan yang merugikan warga seperti tersendatnya dana dari pemerintah pusat untuk desa tersebut yang akan menimbulkan konfil-konfik internal. Kedua, siap atau tidak siap perangkat desa harus mau mengelola anggaran desa dengan transparan dan akuntabel. Pemerintah desa yang transparan dan akuntabel berkewajiban mempelajari sistem pembayaran, sistem akuntasi, dan pelaporan sesuai dengan pertauran perundang-undangan yang berlaku sebagai bentuk akuntabilitas kepada publik. Kepala desa bertugas dan berwenang membuat kebijakan. Kebijakan itulah yang nanti dilaksanakan perangkat desa dimana faktor pembiayaannya akan dilakukan bagian keuangan desa atau kasir. Penggunaan anggaran harus sesuai peraturan desa yang dimusyawarahkan antara kepala desa, masyarakatdan badan permusyawaratan desa. Misalkan anggaran digunakan untuk gaji perangkat desa dan biaya operasional desa yang nilainya sudah disetujui semua perangkat desan dan BPD atas sepengetahuan tokoh masyarakat. Semua kegiatan anggaran harus dilakukan dengan transparan dengan laporan keuangan yang terbuka kepada warga setempat. Laporan tersebut harus dipasang di papan pengumuman yang berada di kantor desa, sehingga warga dapat mengetahui anggaran digunakan untuk apa saja, misalkan selama bulan januari dana operasional desa dipakai menggaji kepala desa, sekretaris desa, bendahara desa, perangkat desa, dan seterusnya. Dana desa juga bisa digunakan untuk membantu masyarakat yang sedang membutuhkan modal usaha pertanian. Namun mekanisme tata cara penggunaan anggaran desa untuk modal kelompok petani dan peternak di desa harus bisa dipertanggung jawabkan. Jangan sampai dalam penggunaan dana dsa tersebut tidak tepat sasaran yang akan menimbulkan kerugian utnuk warga desa. 
Pemerintah desa yang transparan juga harus melibatkan warga desa secara aktif dalam hal musyawarah dan penyaluran anggaran untuk pembangunan desa tersebut. Dengan pemerintah desa yang transparan dan akuntabel, maka anggaran yang diberikan pemerintah pusat dapat dimanfaatkan dengan benar dan tidak terjadi kecurigaan antara warga dan perangkat desa. Ketiga, dalam penyaluran anggaran harus adanya pengawasan yang dilakukan oleh masyarajat melalui Badan Permusyawaratan Desa dan pemerintah diatasnya yaitu pemerinta kota atau kabupaten. Dana desa yang bersumber dari APBN jumlahnya cukup besar maka diperlukan mekanisme kontrol dari mayarakat utnuk mengawasi penggunaan dana desa agar dana desa tersebut dipergunakan sesuai dengan peruntukannya untuk meningkatkan kesejahteraan masyarakat. Namun pada kenyataannya masih kurang pengawasn terhadap dana desa sehingga pemanfaatannya tidak tepat sasaran. Menurut UU Nomor. 6 Tahun 2014 tentang desa Pasal 55C disebutkan bahwa BPD merupakan lembaga yang mempunyai fungsi melakukan pengawasan kinerja kepala desa. Maka dari itu, BPD harus menjalankan perannya secara sungguh-sungguh terutama dalam hal pengawasan terhadap pemanfaatan anggaran desa. Undang-undang dan peraturan pemerintah sudah memberikan payung hukum yang jelas sehingga BPD tidak perlu ragu dalam menjalankan fungsinya untuk melakukan pengawasan terhadap kinerja kepala desa. Adanya mekanisme ceck and balance ini akan meminimalisir penyalahgunaan keuangan desa. Pemerintah dalam pengawasan anggaran juga haurs mengabarkan atau mensosialisasikan informasi kepada seluruh masyarakat desa, tidak hanya diinfokan kepada penjabat atau komunitas desa tertentu saja terkait pemanfaatan anggaran desa. Melalui informasi ini, masyaraat desa memperoleh data atau informasi utnuk melakukan koordinasi penggunaan dana desa tersebut dan sebagai modal pengawasan terhadap pemerintah desanya masing-masing.misalkan dalam satu desa diperoleh dana 1 Milyar, makan informasi terkait penerimaan dana ini harus diumumkan kepada seluruh masyarakat desa secara detail. Namun, pengawasan penyaluran dana desa sebaiknya tidak hanya mengandalkan sistem birokrasi pemerintah saja, tetapi juga harus melibatkan sistem budaya lokal yang berlaku di masing-masing desa. Sehingga sistem yang diterapkan suatu desa bisa saja berbeda dengan sistem di desa lainnya. Pengawasan tehadap anggaran desa menjadikan dana tersebut tidak di salahgunakan, sehingga warga desa merasakan pemanfaatan dana tersebut. Berdasarka penjelasan diatas, peran pemerintan pusat dan daerah serta masyarakat sekitar sangat mempengarui pengelolaan anggaran yang ada di desa. Agar pemanfaatan desa tepat sasaran, pemerintah tidak boleh membuat gap antara perangkat desa dan masyarakat. Warga desa perlu mengetahui kinerja masyarakat desa dengan kata lain transparan dalam hal anggaran untuk pembangunan desa yang lebih maju. Struktur organisasi pun harus dibuat dengan benar sehingga semua perangkat desa menjalankan tugas yang telah ditetapkan, pemerintah desa selalu melaporkan kondisi keuangan yang ada di desa tersebut serta selalu melakukan pengawasan terhadapt anggaran desa agar tidak terjadi penyalahgunaan anggaran desa. Dibalik organisasi maupun perangkat desa yang ideal terdapat kritik dan saran masyarakat yang bersifat membangun untuk progres desa yang ditinggalinya. Masyarakat desa yang cenderung bersifat apatis terhadap politik terutama anggaran desa karena minimnya pendidikan politik yang mengatur kehidupan mereka harus diminimalisir melalui berbagai penyuluhan yang dilakukan oleh orang-orang yang peduli akan pentingnya kemajuan desa terutama dalam anggaran pedesaan.

\subsection{Hukum Adat dan Awig-awig berpengaruh pada Pengelolaan Dana Desa di Bali}

Pemerintah dalam pengertian yang sempit ialah segala aktivas, tugas, fungsi dan kewajiban yang dijalankan oleh Imbaga yang berwenang mengelola dan mengatur jalannya system pemerintahan Negara yang mencapai tujuan Negara . Pemerintahan di Indonesia mulia dari pemerintahan di Indonesia mulai dari pemerintahan pusat, provensi, kanupaten/kota samapai desa. Dalam perjalan ketatanegaraan Indonesia, sistem pemerintahan desa mulai coba diseragamkan lewat UU No. 5 Tahun 1979 tentang Desa, dan kemudian diatur dalam UU No. 32 Tahun 2004 tentang Pemerintah daerah. Desa dengan segenap atribut pemerintahannya adalah arena yang berhadapan langsung dengan 
rakyat. Pemerintahan desa adalah sentra kekuasaan politik lokal yang dipersonifikasi lewat Kepala Desa dan perangkatnya. Posisi pemerintahan desa juga sangat penting, mengingat mayoritas penduduk Indonesia tinggal di pedesaan. Pada prakteknya sistem pemerintahan Desa di Indonesia tidak seragam ini terbukti dari adanya perbedaan dari hukum adat di masing -masing daerah, khusunya di bali dikenal dengn Desa Adat. "Desa adat sebagai desa dresta adalah kesatuan masyarakat hukum adat di Propinsi Bali yang mempunyai satu kesatuan tradisi dan tata krama pergaulan hidup masyarakat umat Hindu secara turun temurun dalam ikatan Kayangan Tiga atau Kayangan Desa, yang mempunyai wilayah tertentu serta berhak mengurus rumah tangganya sendiri".

Dalam Peraturan Daerah Provinsi Bali Nomor 3 Tahun 2001 tentang Desa Pakraman Pasal 5 menyatakan bahwa "Desa Pakraman mempunyai tugas, yaitu membuat awig-awig, mengatur krama desa, mengatur pengelolaan harta kekayaan desa, bersama-sama pemerintah melaksanakan pembangunan disegala bidang terutama dibidang keagamaan, kebudayaan dan kemasyarakatan, serta membina dan mengembangkan nilai-nilai budaya Bali dalam rangka memperkaya, melestarikan, dan mengembangkan kebudayaan Nasional pada umumnya, dan kebudayaan daerah pada khususnya, berdasarkan paras poros, sagilik saguluk, dan musyawarah mufakat, dan juga mengayomi krama desa". hukum adat atau awig-awig merupakan pengikat dari semua aturan yang ada di suatu desa yang menempati posisi pertama sebagai pengatur keberlangsungan tata kehidupan di suatu desa, baik dalam aturan tata krama, upakara, dan dalam pemerintahan Desa pun Awig-awig desa di sebagian desa sangat mempengruhi dalam pengelolaan dana desanya selain dari peraturatan pemeritahan Pusat dan Daerah. Penerapan awig-awig di setiap desa digolongkan menjadi Dua yaitu desa yang berifat Bali Aga (Bali Asli) dan desa yang tidak Bali Aga (Anyar). Dalam Desa Bali Aga Pemerintahan Desa sangat di pengaruhi oleh awig-awig atau hukum adat setempat yang tidak bisa diganti atau dicampur dengan sisitem baru karena masyarakat Bali Aga sangat memprcayai dan menjunjung tradisi yang sudah ada dari turun temurun yang sangat sulit untuk mereka rubah. Desa Bali Aga Dalam pengelolaan keuangan Desanya masih menggunakan cara tradisional dalam pencatatan pencatatan transaksi yang berkaitan dengan pengeloaan dan desa yang ada, ini terjadi karena masyarakat yang masih trdsional dan sangat menjaga apa yang sudah ada dan diwariskan dari leluhurnya, kepala desa adalah tetua yang dipilih dan turunn temurun berbeda dengan desa anyar yang melakukan pemelihan. Faktor inilah yng menyebabkan pengegolaan dana desa di Bali Aga sedikit berbeda dengan desa adat lainnya. Pengaturan penggunaan dana desa yang diberikan oleh pemerintah deerah hanya digunakan sedikit dari desa adat anyar sebab desa bali aga terletak terpencil dan jauh dari pusat pemeintahan daerahnya beda dengan desa anyar yang merupakan desa yang menempati daerah dataran rendah yang menganut system setengah modern dan menerima perubahan sitetem pemerinthan desa adatnya. Dalam pengelolaan dana desa pada desa Bali Anyar pemerintahan desa adat juga melakukan pesangkepan(rapat) dalam menantukan pnggunaan dana desa yang ada dan dibarengi dengan target kinerja pemerintahan. Dalam penggunaan dana desa yang ada membuktikan bahwa pengelolaan dana desa ada dipengaruhi oleh awig-awig desa adat dalam penentuan pengambilan keputusan karena dana desa diserahkan dan pemerintah desa secara langsung diberikan wewenang untuk mengurus dana yang telah diberikan. Dalam sisitem desa adat pengelolan dana desa adat melibatkan masyarakat desa dalam pengelolaannya dan dari sebagian desa adat dibali pengelolaan dna desanya dipengruhi oleh kebijakan desa adat itu sendiri dan hukum desa adatnya.

Penelitian yang kami lakukan mengambil sampel di Desa Banjar Kabupaten Buleleng. Desa adat di Desa Banjar terdiri 5 banjar atau desa dinas pekraman. Setiap melakukan kegiatan dalam pembangunan dan pengelolaan dana desa, desa adat banjar selalu melakukan/mengaadakan sangkepan atau pararum untuk memberikan informasi atau menerima masukan dari masyarakat desa dalam mengelola dana desa sebagian dana desa yang tersisa dari pembangun insfratuktur, pemerdayaan masyarakat, pemerdayaan orgnisasi sekateruna akan dialihkan kepada masing-masing LPD yang ada di Desa Adat untuk membantu masyarakat yang ingin membutuhkan dan dalam menjalankan usahanya sesuai dengan tujuan dari dana desa itu sendiri. 


\section{Simpulan dan Saran}

Berdasarkan penelitian ini dapat disimpulkan beberapa hal mengenai pengaruh hukum adat atau awig-awig terhadap pengelolaan dana desa di Desa Banjar Kecamatan Banjar Kabupaten Buleleng Provinsi Bali, yaitu dalam Peraturan Daerah Provinsi Bali Nomor 3 Tahun 2001 tentang Desa Pakraman Pasal 5 menyatakan bahwa "Desa Pakraman mempunyai tugas, yaitu membuat awig-awig, mengatur krama desa, mengatur pengelolaan harta kekayaan desa, bersama-sama pemerintah melaksanakan pembangunan disegala bidang terutama dibidang keagamaan, kebudayaan dan kemasyarakatan, serta membina dan mengembangkan nilai-nilai budaya Bali dalam rangka memperkaya, melestarikan, dan mengembangkan kebudayaan Nasional pada umumnya, dan kebudayaan daerah pada khususnya, berdasarkan paras poros, sagilik saguluk, dan musyawarah mufakat, dan juga mengayomi krama desa". Hukum adat atau awig-awig merupakan pengikat dari semua aturan yang ada di suatu desa yang menempati posisi pertama sebagai pengatur keberlangsungan tata kehidupan di suatu desa, baik dalam aturan tata krama, upakara, dan dalam pemerintahan Desa pun Awig-awig desa di sebagian desa sangat mempengruhi dalam pengelolaan dana desanya selain dari peraturatan pemeritahan Pusat dan Daerah pengegolaan dana desa di Bali Aga sedikit berbeda dengan desa adat lainnya. Pengaturan penggunaan dana desa yang diberikan oleh pemerintah deerah hanya digunakan sedikit dari desa adat anyar sebab desa bali aga terletak terpencil dan jauh dari pusat pemeintahan daerahnya beda dengan desa anyar yang merupakan desa yang menempati daerah dataran rendah yang menganut system setengah modern dan menerima perubahan sitetem pemerinthan desa adatnya. Dalam pengelolaan dana desa pada desa Bali Anyar pemerintahan desa adat juga melakukan pesangkepan (rapat) dalam menantukan pnggunaan dana desa yang ada dan dibarengi dengan target kinerja pemerintahan. Dalam penggunaan dana desa yang ada membuktikan bahwa pengelolaan dana desa ada dipengaruhi oleh awig-awig desa adat dalam penentuan pengambilan keputusan karena dana desa diserahkan dan pemerintah desa secara langsung diberikan wewenang untuk mengurus dana yang telah diberikan. Dalam sisitem desa adat pengelolan dana desa adat melibatkan masyarakat desa dalam pengelolaannya dan dari sebagian desa adat dibali pengelolaan dan desanya dipengruhi oleh kebijakan desa adat itu sendiri dan hukum desa adatnya.

Berdasarkan penelitian yang dilakukan, adapaun saran yang dapat penulis berikan kepada mahasiswa yaitu agar teman-teman mahasiswa mengetahui bagaimana Pengaruh Hukum Adat atau Awig-awig dalam pengelolaaan dan desa di Bali serta penulis harapkan terutama dari bapak dosen pengampu mata kuliah akuntansi pemerintahan dan rekan pembaca sekalian demi kesempurnaan makalah mini riset ini dimasa mendatang, semoga makalah ini bermanfaat untuk kita semua dan menambah wawasan kita

\section{DAFTAR PUSTAKA}

http://www.pengertianpakar.com/2015/02/pengertian-hukum-adat-dan-sistem-hukumadat.html

http://dhebotblogbelog.blogspot.co.id/2014/01/awig-awig-dalam-desa-pakraman.html http://www.pps.unud.ac.id/thesis/pdf_thesis/unud-1546-1995269459-bab\%20ii.pdf http://www.keuangandesa.com/2015/05/dasar-hukum-pengawasan-dana-desa-oleh-bpd/ http://www.keuangandesa.com/2015/05/dasar-hukum-pengawasan-dana-desa-oleh-bpd/ 